\title{
Of animals and men
}

SIR - I was surprised that Nature thought it necessary to make something of a conundrum of the fact that Charles Darwin was a strong supporter of physiology and recognized the need for experiment on animals. In 1875, largely in response to a vigorous antivivisectionist campaign, the Cardwell Commission was set up. As it was drawing up its report, it became apparent that the government would respond by bringing a bill before parliament. "It was evidently desirable for physiologists to form an association which might come into communication with the minister in whose hands the conduct of the Bill would be placed.... Thus the antivivisection agitation was the cause of the formation of the Physiological Society. Ex malo bonum!"2. Charles Darwin was made one of two honorary members when the society was founded in 1876 . What better credentials could he have?

\section{R. A. Chapman}

School of Veterinary Science,

University of Bristol,

Park Row.

Bristol BS1 5LS, UK

1. Nature 356, 644, (1992).

2. Scharpe-Schafer, E. History of the Physiological Society during its First Fifty Years, 1876-1926 (Cambridge University Press, 1927).

SIR - Christopher Anderson (Nature 356, 3; 1992) records the surprise of National Institutes of Health (NIH) scientists at the speed with which Bernardine Healy ordered an inquiry into a case of alleged abuse of animals. The surprise itself is alarming, however, in the light of the description of the conditions that inspired the complaint: ". 48 cats, many of which had been surgically blinded ... a respiratory infection that many had developed during travel. The cats were inadvertently allowed to breed during quarantine, and most of the kittens died."

If complaints about such a deplorable state of affairs actually require nothing less than an "animal rights movement", then the level of ethical sensibilities within NIH would appear to be as low as the "activists" say. I found the nearly casual reference to Dr Rauschecker's “. . investigating neural plasticity" frankly sobering, coming as it did at the end of this catalogue of horrors.

In commenting on the success that People for the Ethical Treatment of Animals enjoyed by directing a complaint to Healy, Anderson observed that it ". . . makes it likely that animal rights activists will use the tactic again". Tactic, indeed!

\section{Daniel N. Robinson}

Georgetown University,

Washington, DC 20057, USA
SIR - David Porter (Nature 356, 101; 1992) leaves one crucial matter unresolved: is his ethical scoring system intended as a legal set of rules, or as a self-audited guideline for researchers?

If it were used to establish legal constraints over the use of animals in laboratories, it should also be applied to the use or keeping of animals on farms or as pets. The Royal Society for the Prevention of Cruelty to Animals would no doubt confirm that there is large-scale animal suffering outside the laboratory. Further, this is often inflicted for no better reasons than profit, neglect or just plain cruelty. Why should scientific experimentation be singled out for such detailed ethical analysis?

If, on the other hand, the system is to be used as a self-imposed guideline for researchers, surely is is unnecessary. The overwhelming majority of researchers are as concerned as Porter for the welfare of the animals they use. Attaining what would be a low (ethical) score in the proposed system would be natural to these people already. Those (very few) researchers who have a scant regard for animal suffering will simply ignore the guidelines.

The fact is that ethics are personal, and trying to draw accepted boundaries between what is and is not ethical is impossible. What really matters, in a practical sense, is what is legal. So, back to the original question: for what purpose is the scoring system intended? If it is a tool to establish legality, I believe that the scientific community should think very hard before putting it forward as a recommendation.

\section{P. A. Leonard}

\section{Park Mansions,}

London SW1, UK

- On page 102 of Dr Porter's article referred to above, the second sentence in the second paragraph in the section 'Scoring the science' should have read: “ . . . but given the fairly high probability that it will not do so, it is difficult to justify the inflicting of suffering in such inquiry". The word 'quantify' was inadvertently substituted for 'justify' in the published text.

SIR - Frederick Goodwin, of the Alcohol, Drug Abuse, and Mental Health Administration (ADAMHA), recently created a political storm by suggesting that research on aggression in monkeys might help us to understand problems of inner-city males. Jeffrey Mervis's News article on this event (Nature 356, 6; 1992) seems to me unbalanced.

It quoted individuals critical of the content as well as the language of Good-

Letters submitted for Correspondence should be typed, double-spaced, on one side of the paper only. win's statement, but it offered no contrary view. Yet officials of four societies, including the American Psychiatric Association and the Society for Neuroscience, had made public statements or written letters defending the content of Goodwin's message.

I have also been informed that there has long been tension in ADAMHA between supporters of research based on the biomedical sciences and individuals who see mental illness as mostly social in origin. Goodwin, who has been a vigorous advocate of the first view (and a most articulate opponent of animal rights extremists) has inevitably been opposed by the second group. Your reporter does not seem to have sought out this relevant background material.

There are important issues at stake for the scientific community. If we agree that Goodwin's choice of words was unfortunate (for which he promptly apologized), the deeper question is whether the message itself, defending the relevance of animal studies to problems of mental health, is to be subject to political censorship. Such a reaction seems very possible, however carefully the message is phrased. And if such animal research is discouraged, what are the implications for cancer research in mice, or for cardiac research in dogs?

Bernard D. Dayis

Harvard Medical School,

Boston, Massachusetts 02115, USA

SIR - In Donald Hayes' ranking of lexical difficulty (Nature 356, 739; 1992), his most demanding test is an article from Nature, while his easiest is "farm workers talking to dairy cows". Simple language presumably maximizes their milk yields. I suggest a control experiment - reading Nature to dairy cows.

\section{David Jones}

Physical Chemistry Department, University of Newcastle upon Tyne Newcastle upon Tyne NE1 7RU, UK

\section{Correction: Measuring animal well-being}

in a letter from Andrew J. Wilson published on 16 April (Nature 356, 556; 1992), a line was inadvertently omitted from the fourth paragraph, which should read as follows:

The major problem, however, is to decide which measurement of productivity to use. To quote from a review of this problem in respect of poultry ${ }^{5}$, "a change in an environment variable may reduce the number of eggs produced, but increase egg weight, leaving egg mass output the same. Depending on the measure of productivity selected, the change could be said to reduce, increase or unaffect performance." This may seem to be an extreme example, but in the course of investigating the welfare of several species of farm animal over the past few years, I have found that producers do indeed use such arguments. 